\title{
A RAINFALL SIMULATOR FOR THE IN SITU STUDY OF SUPERFICIAL RUNOFF AND SOIL EROSION
}

\author{
Claudia Sangüesa ${ }^{1 *}$, José Arumí ${ }^{2}$, Roberto Pizarro ${ }^{1}$, and Oscar Link ${ }^{3}$
}

\begin{abstract}
A rainfall simulator is an important tool for the study of runoff generation and soil loss because it can be used either under laboratory conditions, or in disturbed or natural soil. The objective of this study was to describe the design and operation of a rainfall simulator to evaluate soil loss in situ. The rainfall simulator has four full-cone spray nozzles with a Unijet system mounted in a straight line pipe configuration, and easily transported and assembled. Simulated rainfall uniformity was evaluated in the laboratory, whereas the applicability of the simulator in natural soil erosion plot conditions in an experimental field with different slopes was tested by quantifying runoff and evaluating soil erosion. Twenty simulations were carried out in the laboratory and sixteen in the field with slopes of 11,21 , and $39 \%$. Four water-sprinklers in a straight line generated rainfall with uniformity close to $90 \%$. The constructed simulator was easy to use and low cost, facilitating the necessary experimental replicates to achieve a suitable spatial representation of superficial runoff and soil loss on hillsides.
\end{abstract}

Key words: soil erosion, superficial runoff, erosion plot, uniformity of rain.

\section{INTRODUCTION}

A rainfall simulator allows generating rainfall with a known intensity and duration on an erosion plot in a controlled manner, making it possible to quantify superficial runoff and soil loss, while at the same time allowing very detailed erosion predictions (MartínezMena et al., 2001). In this way, simulators have widely contributed to the understanding of soil erosive processes, and though there are differences between natural and simulated rainfall, it is possible to find good correlations between the values of soil loss measured in an erosion plot under simulated rainfall and what occurs in a watershed (Hamed et al., 2002). On the other hand, data generated in the measurements allow calibrating, validating, and verifying erosion predictive models such as Universal Soil Loss Equation-USLE (Wischmeier and Smith, 1978).

Various studies can be found in specialized literature where a rainfall simulator has been used to analyze the different processes involved in erosion. Martínez-Mena et al. (2001) studied changes in the physical properties of the soil

${ }^{1}$ Universidad de Talca, Facultad de Ciencias Forestales, Casilla 747, Talca, Chile. "Corresponding author (csanguesa@utalca.cl).

${ }^{2}$ Universidad de Concepción, Facultad de Ingeniería Agrícola, Casilla 537, Chillán, Chile.

${ }^{3}$ Universidad de Concepción, Facultad de Ingeniería, Casilla 160-C, Correo 3, Concepción, Chile.

Received: 10 October 2008.

Accepted: 21 April 2009. in $2 \times 2 \mathrm{~m}$ plots by means of eight 20-min simulations. The simulator consisted of a square frame, $2.5 \mathrm{~m}$ side, supported by four $3.6 \mathrm{~m}$ pillars. Two types of nozzles were used: the first worked at $100000 \mathrm{~Pa}$ pressure with $33 \mathrm{~mm} \mathrm{~h}^{-1}$ rainfall intensity, and the second used $90000 \mathrm{~Pa}$ and $60 \mathrm{~mm} \mathrm{~h}^{-1}$ intensity. The rainfall uniformity coefficient was 89 and 91 , respectively. The simulator's low consumption of water is emphasized, approximately 200 and $350 \mathrm{~L}$ for the low and high intensities, respectively, for a 20-min simulation.

Cornelis et al. (2004) constructed a wind tunnel and a rainfall simulator to study the effect of wind and rainfall characteristics on soil erosion. The simulator consisted of three pipes covering a $12 \times 1.2 \mathrm{~m}$ section with sprinklers working with pressurized water. Arnaez et al. (2007) used a rainfall simulator to compare runoff and sediment production under distinct rainfall intensities in a vineyard plantation in Spain. The simulator consisted of a sprinkler located at a height of $2.5 \mathrm{~m}$ with pressurized water for 30 -min simulations on a $0.45 \mathrm{~m}$ diameter plot. Three different types of sprinklers were used for three rainfall intensities: < 40, between 45 and 70 , and $>70 \mathrm{~mm} \mathrm{~h}^{-1}$. The authors mention in their conclusions that both the reduced plot size and the difficulty to reproduce natural rainfall limit the information obtained.

Aoki and Sereno (2006) used a micro rainfall simulator to study water infiltration in the soil in a 0.25 x $0.25 \mathrm{~m}$ plot consisting of an acrylic drop box in with 49 plastic in its base tubes to form drops with water 
pressure being provided by the height of the water reservoir. Drops with an average diameter of $4.7 \mathrm{~mm}$ were produced. Kinetic energy was $12.7 \mathrm{~kJ} \mathrm{~m}^{-2} \mathrm{~m}^{-1}$ for a $1.5 \mathrm{~m}$ drop height. Sheridan et al. (2008) used a simulator to obtain a modified erodibility index which could be used to predict annual erosion rates for forest roads. They used a rainfall simulator on $1.5 \times 2.0 \mathrm{~m}$ plots, and carried out simulations for 30 min with an intensity of $100 \mathrm{~mm} \mathrm{~h}^{-1}$ and an estimated kinetic energy of $0.295 \mathrm{MJ} \mathrm{ha}^{-1} \mathrm{~mm}^{-1}$, which is similar to the kinetic energy of high intensity rainfall. In Chile, Lagos (2006) and Verbist et al. (2009) used a rainfall simulator documented in CAZALAC (2004) to study hydric erosion and compare distinct methods of measuring soil loss. The simulator consists of a straight line of seven sprinklers with a $1 \mathrm{~m}$ space between sprinklers that work with pressurized water and cover an area of $5 \times 2 \mathrm{~m}$. Verbist et al. (2009) obtained soil loss values in 10 plots with bare soil in the Coquimbo Region. Each experimental simulation lasted $20 \mathrm{~min}$, system pressure was $100000 \mathrm{~Pa}$, and rainfall reached a mean intensity of $130 \mathrm{~mm} \mathrm{~h}^{-1}$.

The most important characteristics of a rainfall simulator are cost, transport and assembling, capacity to generate homogeneous rainfall, and water consumption. The objective of this study was to describe the design and functioning of a rainfall simulator constructed to measure soil loss in situ. For this purpose, the practical experience of assembling and using this device in the laboratory and field are made known.

\section{MATERIALS AND METHODS}

\section{Rainfall simulator design}

The constructed simulator was a continuous sprinkler system with pressurized water (Figure 1). Supply and discharge consisted of an elbow to connect a water supply hose to the sprinkler system, two fast closing cutoff valves: one opening or closing the interflow of water to the sprinklers and another allowing the discharge of water from the system when the sprinkler interflow was closed (connected to an evacuation hose); furthermore, it had a pressure regulation valve for the functioning of the sprinklers. With the discharge valve, cutoff time of water in the sprinklers was minimized, time which would be greater if the pump were directly cut off. A dual pump with a $30.5 \mathrm{~cm}^{3}$ cylinder and $1 \mathrm{~kW}$ power was used in the system. Pipes were polyvinyl chloride (PVC) with a diameter of $32 \mathrm{~mm}$ and the sprinkler system was made up of four full-cone Unijet sprinkler spray nozzles (model TG-SS14W, Spraying Systems Co., Wheaton, Illinois, USA) located on a straight line with a $1 \mathrm{~m}$ space between sprinklers, interconnected by PVC pipes, terminals, and two manometers located one in the front and the other at
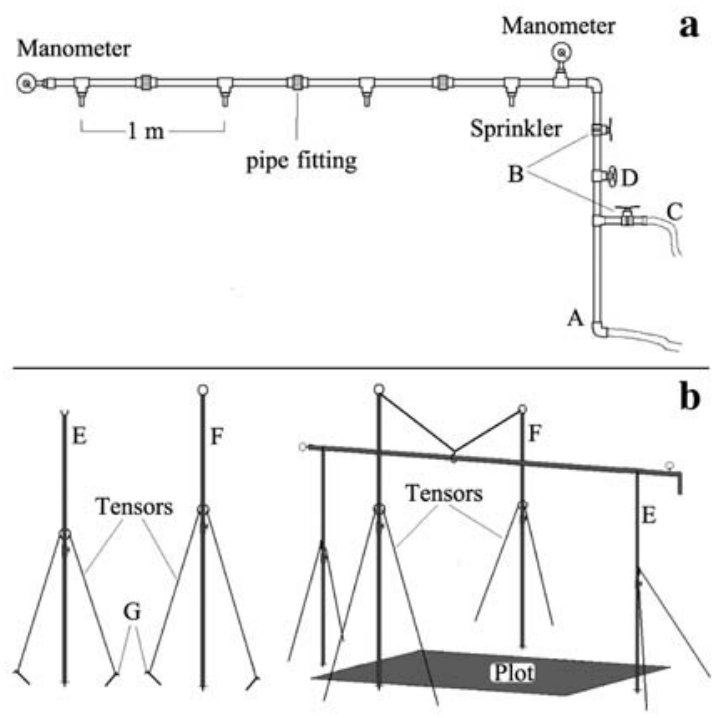

Figure 1. (a) Diagram of rainfall simulator, and (b) supporting structure; (A) water supply, (B) fast closing cutoff valves; (C) evacuation hose, (D) pressure regulating valve, (E) pipe support, (F) lateral pipe support, $(\mathbf{G})$ stakes for tensile ropes.

the end of the system controlling working pressure. Pipe fittings facilitated the vertical position of the sprinklers.

The support of the structure was on a base of four iron pillars ( $2 \times 1 \mathrm{~cm}$ profile) buried $5 \mathrm{~cm}$ in the soil and reinforced by wires and stakes. A polyethylene mesh was used as a windbreak screen with $65 \%$ shade reinforced by stakes and tensed with a system of ropes to generate rainfall under no-wind conditions, which influences the erosive characteristics of simulated rainfall (Erpul et al., 2002). Figure 1 shows a diagram of the rainfall simulator.

\section{Evaluation of rainfall simulator}

The rainfall simulator was evaluated for: 1) cost, 2) transport and assembling, 3) homogeneousness of rainfall, and 4) water consumption.

Rainfall provided by the sprinklers, as well as its uniformity, was tested in the facilities of the Hydric Resources Laboratory of the Facultad de Ingeniería Agrícola, Universidad de Concepción, Chillán, Chile. Homogeneousness of simulated rainfall was characterized by the Christiansen's uniformity coefficient (CU) according to the following equation:

$$
C U=100 \mathrm{x}\left(1-\frac{\sum|x-\bar{x}|}{\sum x}\right)
$$

where $x$ is the height of the water registered for each container on a uniformly spaced grid and $\bar{x}$ is the mean height registered in the containers. 
Sprinklers were evaluated in the laboratory under two working pressures: 75000 and $100000 \mathrm{~Pa}$. Tests were carried out for each sprinkler, first separately and then for the four sprinklers located in a straight line to characterize rainfall through tipping buckets located in a $25 \times 25 \mathrm{~cm}$ grid on the soil, covering an area of $2 \times 2 \mathrm{~m}$ for each sprinkler, and $1.25 \times 3.25 \mathrm{~m}$ for the four sprinklers in a straight line.

The functioning of the simulator in field conditions was tested in three sites with average slopes of 11, 21, and $39 \%$. Three $2.5 \times 1 \mathrm{~m}$ plots were established in each site. Sites were located in the commune of Ninhue, in the dryland zone of the Bío Bío Region, $45 \mathrm{~km}$ West of the city of Chillán. Water supply for the land came from a well.

\section{RESULTS AND DISCUSSION}

\section{Cost}

The construction cost of the simulator was $\$ 200000$ Chilean pesos (US\$400) including water hoses. The operational cost (only fuel for the pump motor was considered) did not exceed $\$ 500$ (US\$1) for $20 \mathrm{~min}$ of operations (approximate performance of the pump was $\left.3 \mathrm{~L} \mathrm{~h}^{-1}\right)$.

\section{Simulator transport and assembling}

The designed simulator was easily transportable given its small volume (Figure 2). A pick-up truck can be used to transport it since the hoses and the windbreak mesh take up the most space. Assembling the simulator in the field can be done by two people. Assembling time varied according to field conditions, especially the slope, but did not exceed $30 \mathrm{~min}$. The simulator must be installed following the slope line of the field, and verifying a structure height of $1.8 \mathrm{~m}$ at both ends.

\section{Homogeneity of simulated rainfall}

An individual sprinkler wets a circumference with an approximate $1.8 \mathrm{~m}$ radius (Figure 3 ). A $2 \times 2 \mathrm{~m}$ square was controlled in the trial, obtaining a mean rainfall uniformity of $86 \%$, a minimum of $84.9 \%$ and a maximum of $87.4 \%$. Furthermore, the $1 \times 1 \mathrm{~m}$ central zone was controlled and showed a mean uniformity of $91.4 \%$ (minimum $90.5 \%$ and maximum $92.0 \%$ ). Similarly, in the tests of the four sprinklers in a straight line, a CU greater than $90 \%$ was obtained for a $1 \times 2.5 \mathrm{~m}$ effective area with pressures of 75 and $100 \mathrm{kPa}$, and rainfall means of 124 and $119 \mathrm{~mm} \mathrm{~h}^{-1}$. The $\mathrm{CU}$ value obtained was considered acceptable (Martínez-Mena et al., 2001). For the above-mentioned, it is recommendable that the effective work area be greater than $2.5 \mathrm{~m}^{2}$. Another important aspect is turning on and cutting off water in the
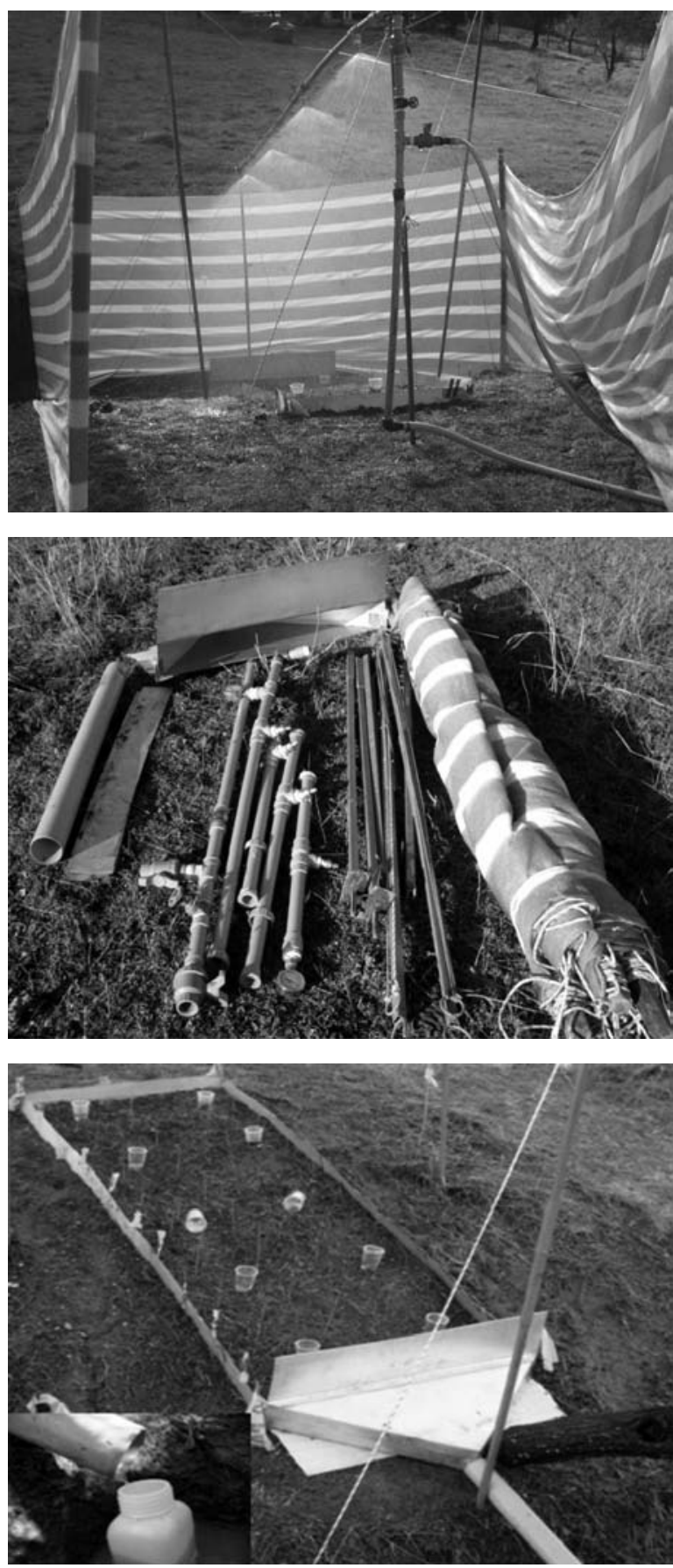

Figure 2. The top picture shows the rainfall simulator installed on a soil erosion plot with a $40 \%$ slope. The center picture shows the dismantled simulator. The bottom picture shows detail of the soil erosion plot, and runoff and sediment sampling.

sprinklers in a minimum amount of time using fast closing cutoff valves to produce a greater homogeneousness of rain at the start and end of each simulation. 


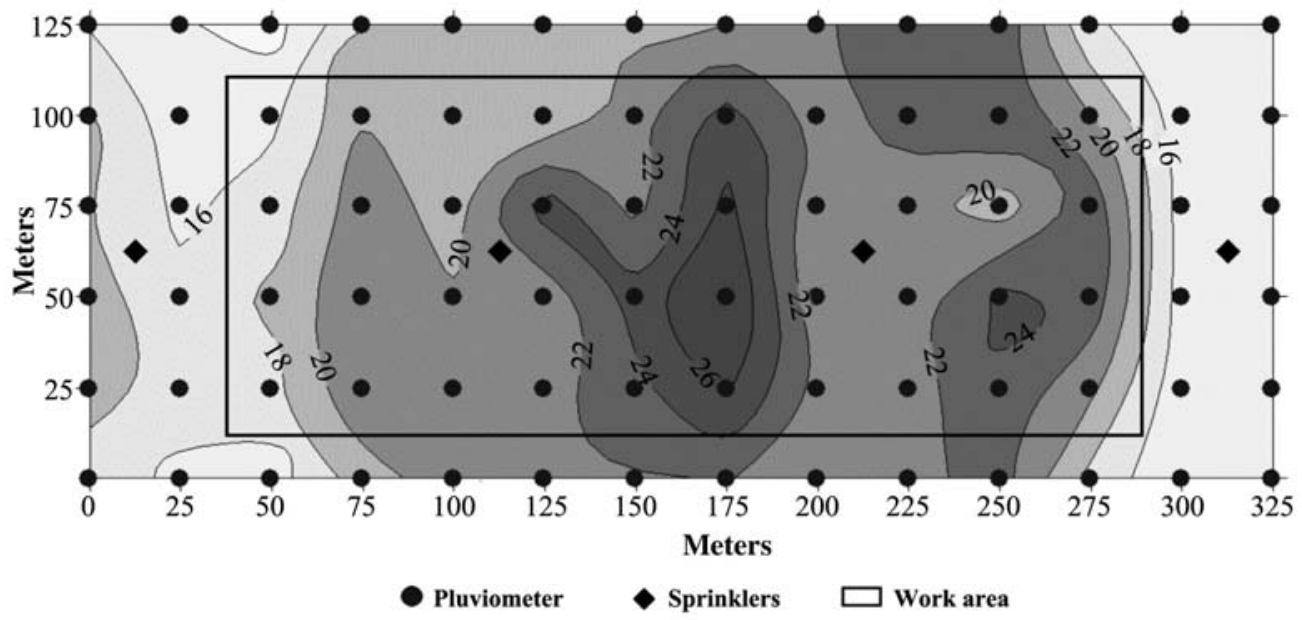

Figure 3. Spatial distribution of rainfall $(\mathrm{mm})$ simulated with four water sprinklers in a 10-min test with pressure of 100 kPa. The interpolation method used is linear interpolation with triangulation.

\section{Water consumption}

Water consumption of the rainfall simulator was $1800 \mathrm{~L}$ $\mathrm{h}^{-1}$. Real consumption in a simulation is a function of time which depends on the initial soil water content. For low soil water content, between 5 and $6 \%$, simulation times between 50 and $60 \mathrm{~min}$ are required to generate minimum runoff. For high soil water content, near $20 \%$, simulation time required varies between 10 and $20 \mathrm{~min}$.

\section{CONCLUSIONS}

The rainfall simulator shown can be used for an in situ study of soil loss. It was used in erosion control plots on natural hillsides and generation of runoff and sediment transport was verified for each simulation.

Results of laboratory and field tests allowed evaluating uniformity of the rainfall generated and the applicability of the simulator on erosion plots with different slopes. The simulator generated adequate homogeneous rainfall to study processes of superficial runoff and erosion with uniformity near $90 \%$.

Finally, the constructed simulator was an easy to use tool, low-cost, and easy to transport and assemble in the field, thus allowing the necessary experimental replicates to be carried out.

\section{ACKNOWLEDGEMENTS}

The authors thank the Comisión Nacional de Investigación Científica y Tecnológica (CONICYT) for the financing of the first author in the Master's program, and to the Instituto de Investigaciones Agropecuarias, INIA Quilamapu for providing its field facilities.

\section{RESUMEN}

Un simulador de lluvia para el estudio in situ de la escorrentía superficial y la erosión de suelos. El simulador de lluvia es una herramienta importante que permite estudiar los procesos de pérdida de suelo y escorrentía generados por la acción de la lluvia; éste puede utilizarse en laboratorio, bajo condiciones de suelo removido, o en terreno en condiciones naturales de suelo. El objetivo de este estudio fue describir el diseño y el funcionamiento de un simulador de lluvia construido para medir la pérdida de suelo in situ. El simulador de lluvia tenía cuatro boquillas de aspersión de cono lleno con sistema Unijet (Spray nozzles) ubicados en línea, alimentadas mediante un sistema de tuberías de fácil transporte y montaje. En pruebas de laboratorio se evaluó la uniformidad de la lluvia generada; mientras que en terreno se evaluó la aplicabilidad del simulador sobre parcelas de erosión ubicadas en laderas naturales con diferentes pendientes, donde se cuantificó la escorrentía superficial y la erosión del suelo. En total se realizaron 20 simulaciones en laboratorio y 16 en terreno con pendientes de $11 ; 21$ y $39 \%$. Los cuatro aspersores en línea generaron una lluvia con una uniformidad cercana al $90 \%$. El simulador construido fue una herramienta de fácil uso y bajo costo, que facilitó la realización de las repeticiones experimentales necesarias para lograr una adecuada representatividad espacial de la escorrentía superficial y pérdida de suelo en laderas.

Palabras clave: erosión del suelo, escorrentía superficial, parcelas de erosión, uniformidad de la lluvia. 


\section{LITERATURE CITED}

Aoki, A.M., y R. Sereno. 2006. Evaluación de la infiltración como indicador de calidad de suelo mediante un microsimulador de lluvias. Agriscientia 23:23-31.

Arnaez, J., T. Lasanta, P. Ruiz-Flaño, and L. Ortigosa. 2007. Factors affecting runoff and erosion under simulated rainfall in Mediterranean vineyards. Soil Tillage Res. 93:324-334.

CAZALAC. 2004. Simulador de lluvia, construcción y especificaciones. 12 p. Nota Técnica. Centro del Agua para Zonas Áridas y Semiáridas de América Latina y El Caribe, La Serena, Chile.

Cornelis, W.M., G. Erpul, and D. Gabriels. 2004. The I.C.E. Wind tunnel for wind and water interaction research. p. 59-68. In Visser, S.M., and W.M. Cornelis (eds.) Wind and rain interaction in erosion (trmp 50). Tropical Resource Management Papers, Wageningen University and Research Centre, Wageningen, The Netherlands.

Erpul, G., L.D. Norton, and D. Gabriels. 2002. Raindropinduced and wind-driven soil particle transport. CATENA 47:227-243.

Hamed, Y., J. Albergel, Y. Pépin, J. Asseline, S. Nasri, and P.Zante. 2002.Comparison between rainfall simulator erosion and observed reservoir sedimentation in an erosion-sensitive semiarid catchment. CATENA 50:1-16.
Lagos, E. 2006. Caracterización del proceso precipitaciónescorrentía sólida utilizando un simulador de lluvia. 103 p. Tesis Ingeniero Forestal. Universidad de Talca, Facultad de Ciencias Forestales, Talca, Chile.

Martínez-Mena,M.,R.Abadía,V.Castillo,y J.Albaladejo. 2001. Diseño experimental mediante lluvia simulada para el estudio de los cambios en la erosión del suelo durante la tormenta. Rev. C. \& G. 15(1-2):31-43.

Sheridan, G.J., P. Noske, P. Lane, and C. Sherwin. 2008. Using rainfall simulation and site measurements to predict annual interrill erodibility and phosphorus generation rates from unsealed forest roads: Validation against in-situ erosion measurements. CATENA 73:49-62.

Verbist, K., Cornelis, W. M., Gabriels, D., Alaerts, K., and Soto. G. 2009. Using an inverse modelling approach to evaluate the water retention in a simple water harvesting technique. Hydrol. Earth Syst. Sci. 13:1979-1992.

Wischmeier, W.H., and D.D. Smith. 1978. Predicting rainfall erosion losses - a guide to conservation planning. Agriculture Handbook $\mathrm{N}^{\circ}$ 537. U.S. Department of Agriculture, Washington D.C., USA. 